\title{
A Discussion of and Suggestions to the Problems in Chinese Family Education
}

\section{-Based on the Observations of American Family Education}

\author{
Fang Zhou, Tao Jiang
}

The School of Public Finance and Public Administration, Jiangxi University of Finance and Economics, Nanchang, China

Email: ruthzjleni@163.com

How to cite this paper: Zhou, F., \& Jiang, T. (2017). A Discussion of and Suggestions to the Problems in Chinese Family Education. Creative Education, 8, 347-358.

https://doi.org/10.4236/ce.2017.83027

Received: February 12, 2017

Accepted: March 10, 2017

Published: March 13, 2017

Copyright (c) 2017 by authors and Scientific Research Publishing Inc. This work is licensed under the Creative Commons Attribution International License (CC BY 4.0). http://creativecommons.org/licenses/by/4.0/

\begin{abstract}
Family education comes first in all the educational forms one receives. Many educational experts all over the world all agree that its first and foremost role and impacts can last throughout one's life. The necessity and importance of studying family education, esp. in this rapidly transformational and globalized world with increasingly fierce competition, have reached an unprecedented level for many countries. This paper mainly describes the current common problems in China's family education, analyzes the reasons for them and tries to help solve them with the good practices drawn from the family education in the U.S., and provides some suggestions for parents in both countries in the hopes of improving and complementing each other in this area.
\end{abstract}

\section{Keywords}

Family Education, Ideology, Observations, Complement

\section{Introduction}

Family education refers to the education, guidance, influences taking place among family members, with the most common definition being the teaching and nurturing of the children by parents or other seniors. In order to adapt to the modern era and cultivate more competitive and innovative talents for our country, Chinese parents should pay attention to the problems in parenting and learn from the successful experience of American parents, who have yielded relatively remarkable achievements in this regard recognized the world over. Aside from learning from them in terms of ideology, objectives, means, contents, some suggestions are also given to American parents for the two to complement each other and improve together.

The aim of this paper is to try to contribute to the theory study and practices 
on Chinese family education from both academic and empirical perspectives.

This article first compares the fundamental educational ideologies of China and the US, because ideology determines the corresponding educational means and contents. Then it offers a detailed analysis and description of the differences in seven aspects in terms of educational means and contents adopted by Chinese parents and American parents as well as the reasons behind them. Next, similarities between Chinese and American family education are provided, followed by suggestions on Chinese family education regarding educational objectives, educational contents, parents' own aspect, school and national aspects. In the end, a conclusion on family education based on the analysis above was reached.

\section{Comparison between Chinese and American Family Education}

\section{General Ideology: Utilitarian vs. Individualistic}

The general educational ideology of most Chinese people, unfortunately, tends to be utilitarian and functional, which is influenced by the ancient Chinese social values about education, "The worth of other pursuits is small; The study of books excels them all." Chinese people in ancient times had to be scholars to gain a high social status, a bureaucratic title and fame. Likewise, Chinese people nowadays still have to resort to educational means, such as the Gaokao, for a possible better life, a decent job, a higher social status and some glory as well. And the situation is by no means less serious given the increasingly fierce competition from home and abroad. So naturally, the objectives of Chinese family education are most likely to cultivate useful talents that are good at scoring high marks and securing a good life and the possibility of class mobility to a higher social status (Wang, 2008).

However, in contrast, the educational ideology of American education is the acquisition of happiness, the development of individual interest and potential and the cultivation of character (Erikson, 1993). Therefore the objectives of American family education are to cultivate happy individuals first and foremost, and achieve personal fulfillment hopefully in any form that demonstrates personal value and uniqueness. Children in the US don't have to face the same amount of pressure of getting high marks or becoming useful to get recognition from their parents and win their love and support. Their parents just love them unconditionally, believing every kid deserves parents' love, whether he or she is bright, excellent and beautiful or not. Numerous studies show that kids growing up with this kind of unconditional love are far more likely to be confident, happy and thus make accomplishments.

Of course, economic situation and national development are also crucial factors. Living in the world's super power with a very strong economy, American people have more employment opportunities and choices. Therefore, they tend to be more open-minded about marks, study and even jobs, believing every job is valuable and should be respected. In contrast, in China, with a relatively less developed economy, more tense competition and a tough job market, education 
still remains the only common way to make the change.

\section{Educational Means \& Contents}

With the two different educational ideologies and objectives taking root, parents in both countries will probably adopt different means of teaching. The following are some of the most common problematic ones in today's Chinese family education, with specific reasons behind them also provided:

\subsection{Intelligence Cultivation vs. Character Cultivation}

Nowadays most of the Chinese parents are mired in the great anxiety of fearing their children might be left behind and lose at the starting line of education. Then they attach too much importance to the gaining of knowledge and skills by registering their kids in all kinds of extracurricular classes and activities, such as reciting poems, learning English, dancing and playing musical instruments, and even Olympian Math., with the goals being achieving high marks and becoming useful. All this leads to the common consequence that the kids are unhappy, stressful and even have psychological problems because other key aspects in education are neglected, such as character-building, horizon-widening and values-shaping areas.

Instead of investing in intelligence and skill cultivation, American parents attach great importance to character cultivation, one goal of which is to cultivate a happy individual, because a happy mood is a kind of human right critical to making achievements of any kind. So American parents don't usually force their kids to take too many extracurricular courses to raise grades. Kids are not under too much academic pressure. However, to make their kids optimistic, confident, positive and good at learning and thinking independently, American parents do think highly of some specific tasks for their children, such as developing the habit of reading, taking part in sports and community service, etc, which have all been proven to be the key factors contributing to one's success.

American parents are known in films and TV series for their bed-time stories, which are a must for kids before going to sleep. Though the practice has been followed by many other countries including China in the past few decades, it is still a testament to the great emphasis American parents lay on reading. Normally, American kids start to develop reading habits and abilities at a very early age, with some even at two or three years old. They are taken to the library to feel the atmosphere of reading and join other kids. When kids are in the kindergarten, many parents will make sure that they spend a least 1 hour per week in the public library, learning and searching for information through computers. Like participating in bed-time stories, parents will continue participating in the reading tasks for many years on to facilitate better understanding and communication with their kids. Therefore, the phenomenon that many people in the US choose to indulge themselves in reading on the subway can be accounted for because for most of them, the reading habit has been with them since when they were a kid. Furthermore, reading classical works extensively is a must for culti- 
vating critical thinking and independent writing abilities, which seems the only way to achieve high marks in the US.

Another area that American parents invest money, time and energy heavily in for their children is not academic one but sports. Almost every American family, whether poor or rich, always fills their weekend with sports activities, such as basketball, soccer, swimming or just hiking and climbing. At other times, parents will deliberately create atmosphere for kids to do sports, such as buying sports-related gifts, setting up basketball net or swing in the backyard, or even heading as the coach for ball games for kids. The ultimate purpose of this emphasis is to cultivate healthy individuals, both mentally and physically, with strong physique, good teamwork spirit and perseverance, which are all fundamentals for leading a good life (Li, 1998).

One more area American parents attach importance to is volunteerism, which is also well known and learned by many countries throughout the world. Many American citizens have the experience of volunteering for communities and the society. Therefore, new generations will certainly be positively influenced. Kids are encouraged or even required to volunteer at a young age. Primary school students are often assigned with some simple house chores or delivery services, such as cleaning cars for parents, mowing the lawns, taking care of pets or delivering milk and newspapers for neighbors. When students reach middle school, they will provide more social services, such as helping people in hospitals and nursing homes or homeless people, working for charity organizations, libraries or museums. By engaging in volunteering for social services, students not only get first-hand experience with the society but also credit, respect and an advantage for applying for universities! And in the process, they become more loving, caring and responsible for themselves and others.

Admittedly, Chinese parents also value reading books, but more often than not, the purposes tend to be utilitarian, associated with taking exams and getting high marks.

In terms of doing sports, quite a few parents have a limited or wrong understanding of the importance of sports. Some think all that is needed is good nutrition and basic body movements. Some worry exercising might get kids injured or waste their precious time for studying. As for doing volunteering work, many will resort to getting certifications by companies or organisations or merely just show up without doing actual work. Some parents even won't allow their children to participate for fear that their kids are too young to get in contact with the society and that they might be cheated or hurt by adults.

\subsection{Autocratic vs. Democratic}

Due to the influence of the traditional Chinese cultural belief that obedience to parents is considered filial and parents have the right to govern with authority, quite a lot of Chinese parents nowadays are still obsessed with this kind of superiority and are unwilling to empower their kids when it comes to decision makings, whether big or small, ranging from what to eat and wear, what major to 
take, and even whom to marry, in the name of so called "for the benefits of their children" (Li, 2009), but actually these decisions are nothing but their own selfish wishes or even their own unfulfilled dreams. They are very strict or hypercritical with their kids, not allowing them to make any mistakes or fall short of their expectations, some even resorting to violence, both physical, verbal and emotional. It is not hard to imagine that kids growing up deprived of the basic right to decide for themselves and treated with ill attitudes rather than respect and trust are not only painful, frustrated, unconfident and even coward, but also more likely to be less capable of getting things done in the future, let alone succeed. For some rebellious ones, they might even turn against their parents, inheriting the same superiority and autocracy for their next generation. For others, they might even become potential safety threats to the society with the same violence-prone traits inherited from their parents.

In comparison, American parents who believe in democracy and personal rights and freedom often become friends with their kids first. They treat their kids as independent individuals and equals rather than their own personal property that they can randomly order about anytime. They believe every individual has their own choices, hobbies and strengths. Every individual should learn how to survive, how to adapt to the environment and how to solve problems by themselves and that parents are not dictators or nannies but friends, guides and tutors.

\subsection{Doting vs. Adversity-Embracing}

Quite opposite to being autocratic, another serious problem of Chinese parents' is spoiling their kids (Li, 2007). This kind of parents go to great lengths to satisfy almost all the needs of their "little emperors and little princesses", prevent them from any labor, and ignore the mistakes these "little emperors and little princesses" make even at the cost of sacrificing themselves or doing harm to others. The reasons are mainly as follows: First, most of the parents lived a hard life when they were young, given the underdeveloped economy and low living standards prior to the 1990s in China. Therefore, they tend to show love to their kids in such a compensating way to their only child in the family. Second, as mentioned at the beginning, many parents think the only duty of the kids is to study hard and get high marks and that doing house chores or other work unrelated to study is unnecessary. Third, a large group of grandparents are involved as well, with various kinds of mixed reasons. Some might find it a way to compensate their grandchildren out of guilt for their previous lack of parental responsibility; In many cases, the typical 421 family structure, that is, four grandparents, two parents and one child, will likely result in a doting grandparent. And the fact that elderly people become child themselves may also explain the wilful act. But of course this kind of excessive love is abnormal, causing very serious consequences.

American parents will probably highly disagree with this kind of parenting means. Though I mentioned previously they treat their kids as equals and 
friends, yet American parents encourage or require their kids to help do house chores, such as putting away their own stuff, cleaning the house, fetching the newspaper deliveries, mowing the lawn, etc. in order to help them obtain the traits of being responsible, independent and able to solve problems. Some "stone-hearted and cruel" ones even expose their kids to "tough situations" to temper them into individuals with strong will and perseverance that can better cope with difficulties. I once read about several exchange students from the US to China talking about their scariest experience. One student said hers was being sent to a forest with other kids by her parents and spent one week there, without food or water. This sounds a little extreme, but it demonstrates the general attitude of American parents towards the importance of shaping their children's character.

What is worthy of note is the two different results of the two educational approaches. Numerous cases have been reported in China that college students can't take care of themselves or even can't cope with daily operations while in college, with some even choosing to drop out to reunite with their parents. Other cases involve committing crimes. For instance, in 2013, the son of a celebrity couple who are both famous singers in China raped a woman staff worker from a KTV with his other 4 friends. The boy who was younger than 20 then and sentenced 10 years in prison is actually a victim of parents' doting behaviors. $\mathrm{He}$ had committed quite a few cases before this vicious one. Because the couple had their son at a very old age, they, particularly the mother, doted on him to a great extent, ignoring his mistakes, big or small, and satisfying all his needs, with no principles or bottom lines. Consequently, the young boy lost sound judgment and the ability to tell right from wrong and committed the crime, probably thinking he would be pardoned again. Cases like this may be not very typical, but it well demonstrates the disastrous consequences brought about by doting on children.

Whereas, it is almost a common practice for American college students to take several part-time jobs to earn money for their tuition and living expenses (Mason, 2013). They do this not necessarily because they are poor but that they have been accustomed to being independent and responsible for themselves, which is obviously a positive result of constructive family educational means.

\subsection{Moral Education: Collectivism vs. Individualism}

While there are some similarities between the moral education in China and the US, such as the emphasis on love, kindness, virtue and thrift, the two biggest antagonistic aspects are collectivism and individualism advocated in China and the US respectively.

Collectivism originated from ancient China where the individuals must comply with the collective and that all individual benefits must serve those of the collective, such as the tribe and the country. While it is highly desirable to advocate it for the collective benefits of the people and the country, this moral trait has somewhat distorted nowadays in China, leading to some unpleasant conse- 
quences. Many children raised in this modern age of increasing globalization have actually become more selfish, self-centered and even indifferent. In recent years, there have been an increasing number of bullying incidents among all ages of schoolers. I think the terrible situation is caused by the bad moral education these schoolers receive. Parents are also to blame to a great extent. Some may believe the impacts of individualism in the west must also be to blame. However, I would like to make it clear that the individualism advocated in western countries has been misinterpreted for a long time. Authentic individualism is not about being selfishly pursuing personal interests while ignoring or even intruding upon others'. It is about an intense sense of being independent, and shouldering personal responsibility (Wu, 2003), and therefore constitutes the basis of being a good citizen.

Actually sound and healthy individualism is also the basis of a reasonable and effective collectivism.

\subsection{Materialistic vs. Spiritual}

As a former English teacher, I have heard quite a lot of times of parents complaining that their children are "unappreciative" of their sacrifices.

Some mothers are very disappointed to find that their children aren't even able to write a good article about a good mother when they do almost everything for them, such as going to great lengths to cook various kinds of delicious meals, buying beautiful clothes, picking them up every day. It might sound very surprising at first, but as I look deeper, I think there are reasons that can explain their children's "lack of appreciation". Children at different stages of growth need different forms of nutrients. There is a time when material supplies can't satisfy their needs and they need mental and psychological communications from their loved ones to feel being cared about and secure (Wang, 2008). But unfortunately, many Chinese parents don't realise this. All they are concerned about are providing their children with a high-standard life filled with abundant good food, famous-brand clothes, high-tech gadgets, etc. Others are just too shy to express in an open way. Of course, this can be traced back to some traditional Chinese traits, such as shyness and restraint. But the crux is that many just aren't aware of the importance of mental interaction, which is even more critical to one's healthy physical growth in a way. Consequently, the distance between parents and children gets further and further, with some even becoming "the most familiar strangers" to their kids.

In terms of this, American parents generally do a better job either because of their culture or their philosophy of raising kids. As described previously, they treat the kids as friends first and independent individuals that have the same mental problems to solve and inner feelings to share and reveal.

\subsection{Sex Education: Avoidance vs. Instruction}

In China, many children have the baffling experience in which their parents told them they cracked out of a rock like the Monkey King or were simply picked up 
by the streets when they wondered how they came to this world. This may sound like a joke by the parents, but it reveals the poor awareness of sex education in China and unfortunately the situation has changed little.

Due to the traditional cultural belief that sex and sex related-topics are unethical, many Chinese parents including those dating back to the ancient times just choose to avoid mentioning anything about sex or even some basic biological knowledge to their children (Wang, 2014). In modern times, with the increasing competition of taking entrance exams, many others just won't spend time on it because it is an unimportant non-test subject.

The consequences of this are far more direct and serious. The recent occurrence of a tragic crime case in which a high school girl student suffered from sexual assaults from her teacher for a year and was raped several times before her parents found it out shocked the whole country. Reports show that many women had sexual harassment experiences when young but they chose to hide instead of confessing to parents. Many middle school students or even college students don't know about their body and the physiological symptoms at different age stages as they grow. A large number of college students don't know how to protect themselves from STD and avoid becoming the victims of abortion or being a single-mom, not that they are irresponsible but that they simply lack the knowledge!

Speaking of sex-related topics, one will probably think Americans are very open about sex. Actually, as far as I know, it is a kind of misunderstanding or even rumor spread in our country through films or TV soap operas. The fact is American parents attach great importance to sex education starting from when their children are very young. They consider it a responsibility and must to spread sex knowledge to their children. Thus in most American families, a relatively loose and open environment for instructing in and communicating on sex is created where parents and children can communicate freely on sex-related issues. According to a survey conducted by the US Kaiser Family Foundation about teenagers aged between 15 and 17 years old, $41 \%$ said they have talked with their parents about when to have sex with their partners. $43 \%$ said they have told their parents they had exchanged ideas with their partners on sexual health. 52\% said they have talked with their parents about AIDS. Besides the good environment and attitude, American parents also make use of related books, references and guidelines made by the state government to provide more concrete and scientific guidance.

\subsection{Finance Rejection vs. Finance Advocate}

Recently there have been a few reported cases in which some high school students from impoverished families died of heart attack or chose to commit suicide after being swindled of their college tuition fee ranging from 5000 Yuan to 9900 Yuan. Kids from relatively wealthy families also have trouble with money issues but in a different way. Conversely, many of them may have no idea of money, thinking probably everyone will just have enough to spend from when 
they were born, because they themselves have been misspending it with basically no restrictions from their parents. Chinese parents care little about teaching kids about money-related issues, because they think money is wordly and that kids are too young to talk about it, otherwise kids' study might be affected.

However, the attitude towards money in the US is completely different. What's most well known is that American children get paid by the housework they do, a move supposed to help kids understand the value of labour and gain a correct knowledge of how money is made (Li, 2009). In addition, most American parents have fixed amount of pocket money for their children, which is not very generous. Even the world-famous American oil industry business magnate and philanthropist, John D. Rockfeller, who is considered to be the wealthiest man of all time, seemed very "stingy" about money. He even created a contract stating the by-laws of distributing pocket money to his kids of different ages. But obviously he did that not because of being mean but the purpose of cultivating financial management ability for his children and helping them to be thrifty.

\section{Similarities}

Generally speaking, the importance of family education in both countries has been more and more prominent in this modern age, valued ever more by parents. They all wish to do a better job in raising kids and expect their children to succeed and live a happy and good life.

The specific similarities are demonstrated in the following aspects: First, as the world becomes more and more globalised and integrated, parents in two countries have started to know about and learn from good practices from other countries. Second, the main responsibility of parenting falls on the shoulders' of mothers, as in two countries women still play a more important role domestically while men are more likely the breadwinners.

\section{Suggestions on Chinese Family Education}

\subsection{Regarding Educational Objectives}

While it is absolutely right to stick to and carry forward some traditional values, it is also urgent that Chinese parents make some adjustments by abandoning some outdated values and practices that have proved to be ineffective or even harmful to children's growth, such as the purpose of receiving education, the taboo topic of sex education and the notion that children's obedience to parents is filial piety. Just as Karl Marx said "people's ideologies, opinions and concepts change as the living conditions, social ties and social existence change". Therefore, a sounder perception of education is very much needed. Success obtained through high marks instead of a good attitude towards life and study is not lasting and sustainable. The purpose of education is not only to cultivate useful talents that are capable of scoring high marks, landing good jobs and earning money and glory, but to prepare children for becoming independent individuals and qualified social members that can adapt to the society, solve problems, think independently and at the same time communicate with others with understand- 
ing and empathy. This is exactly what General Education advocates in the US, thus explaining the differences between Chinese parents' educational objectives and those of their American counterparts.

\subsection{Regarding Educational Means}

First and foremost, love before teaching. Treat the children as equal individuals rather than affiliations of any kind. They also deserve respect, patience and the right to make their own decisions under the guidance of parents. Neither patronizing nor preaching is the desirable way of parenting. Change the way of expressing love and care for them. Making children feel loved unconditionally by parents is the prerequisite for facing the outside world with courage and bravery as well as achieving success. Secondly, setting good examples for children in many aspects in life is very critical. One can't require their child to behave according to rules when they are obviously neglecting them. For instance, it's exemplary to get along well with other family members, relatives, neighbors and even strangers. The way parents treat others influences children a lot.

\subsection{Regarding Educational Contents}

The first aspect that needs drastic changes urgently and immediately is the attitude towards sports. Unlike that in the US, the advocacy and promotion of doing sports throughout Chinese long history and civilization has been very little because in the ancient times, being physically strong was thought to be uncivilized. But actually, as both science and academia have proved, sports can lead to the sound development of both body and mind. Research shows that exercise enhances ones' mental sharpness. One can only become confident with a healthy and strong body to demonstrate to the world their capability of overcoming difficulties and obstacles. What's more, a nation's development and progress on the international arena is linked with the emphasis one nation lays on sports. For instance, the nation's fighting spirit and spirit of exploration and going on an adventure are determined by sports to a great extent. This has been echoed by some famous Chinese leaders and writers, such as Chairman Mao Zedong and $\mathrm{Lu}$ Xun, with the former urging to develop sports and strengthen people's physique in 1952. The present President Xi Jinping also attaches great importance to sports, claiming being good at sports makes a great nation and that promoting the constant development of Sports cause is one of the most important parts in national rejuvenation.

The second is the moral aspect. It is well known that the moral values in the US have a lot to do with religion, such as Christianity, which provides principles for them to follow in a sacred way. I am not indicating that Chinese parents should also become religious believers but that they can instill solid and correct core principles into their children to make them believers of sincerity, honesty, kindness and empathy, which will help them better judge between right and wrong, get along with and treat others well. Be a person with beliefs before obtaining success. 
The third aspect is reading. While it is understandable to long for high marks in China, parents should be aware of what is fundamental to harvesting high marks. Instead of pursuing high marks only and of forcibly registering the kids at all kinds of extracurricular courses, Chinese parents should really review the importance of cultivating the reading habit. Reading extensively is very beneficial for forming a good personality as well as promising a good life in that through others' countless descriptions, one can learn and experience so much in advance and even get ways to tackle problems and difficulties, form good judgments and sensible values.

The fourth one is volunteering. Don't shield children too much as if they were as fragile as glass. After all, they will eventually have to become social members. Preparing them for this earlier will make it easier for their future.

Meanwhile, it is also necessary to properly create environments where children can taste the difficulties and bitterness of real life so that they can become strong and resilient. Taboo topics such as sex-related education can be conducted according to the guidance of books, teachers or experts.

Learning is by no means just about examinations and cramming. High marks can't guarantee success but a good character with optimism, confidence, strong will and empathy as well as the ability to create, learn and cooperate can lead to far greater chances of success. After all, it makes great sense to say that the ultimate competitive edge between children is a strong physique, a good character and comprehensive ability.

\subsection{Regarding Parents' Own Aspect}

Parents should keep learning and keep up with the times so that they can get more qualified and better informed to instruct and communicate with their children. Participate in professional training organised by schools to become more adept at parenting and knowing children. Never resort to violence when teaching. Be a open-minded, principle-abiding, liberal and trustworthy parent!

\subsection{Regarding School and National Aspects}

As mentioned above, American kids can spend considerable amount of time on reading extensively and doing sports and volunteering services. This can be attributed to the efforts and policies from both their nation and schools. For instance, American students have less homework to finish after school, thus more time at their disposal. Public libraries are easily accessible to every community with abundant reading materials to borrow from for free. Schools across the US value sports education and sports-related tests and competitions a lot and the country also boasts wide-spread good sporting facilities. Students with sports talents and achievements can have great edge when applying for universities. Likewise, volunteering work is also a must to earn enough credit and to win praise and respect.

So considering the great importance of reading, sports and volunteering work, our country and schools should lessen the burden of children to give them more 
time to enjoy other beautiful things other than just cram for exams. More facilities and public infrastructure are needed to provide kids with a better environment to exercise and read. More emphasis should be given on the importance of sports and social volunteering to prepare our kids for becoming physically healthy first, because it is the very basis of having a sound mind. Roll out more professional courses and training for parents to facilitate more and better communication between parents and schools.

\section{Conclusion}

Life is not a short race but a marathon. A good and early beginning can't guarantee a smooth and triumphant arrival. What is more critical is good physique, sound mentality and other good qualities.

As mentioned above, considering the problems in our current family education facing Chinese parents and children, we can learn from the good ideologies and effective practices of American parents accordingly and properly. But American parents can also learn from their Chinese counterparts, esp. ancient Chinese educational ideas, because these ideas share some similarities with those in their country and precious ideas are applicable to people of all races. For instance, the essence of the ancient Chinese sage, Confucius's educational thought is Benevolence, that is, loving others just like loving oneself, which is also the core doctrine of the popular Christianity. As descendants of such a brilliant ancient civilization, we Chinese people should also adjust our attitudes and approaches to it, learn more and make better use of it to benefit better and carry forward these precious thoughts of our great ancestors.

There is no absolutely right or wrong parenting approach, esp. given the different histories and social backgrounds. But we can learn from each other to complement and strike a good balance between the two so that both sides benefit, and precious ancient philosophical thoughts can be inherited, and new ones are created as legacies for our future generations.

\section{References}

Mason, C. (2013). Charlotte Mason Family Education. Shanxi: Shanxi Normal University Press.

Erikson, E. H. (1993). Childhood and Society. New York: Norton.

Li, L. Y. (1998). The Savage Civilization. Beijing: China Society Press.

Li, S. H. (2009). What Does Chinese Family Education Lack? Beijing: Chinese Sanxia Press.

Li, Z. Y. (2007). An Analysis of Chinese and American Family Education and Study of Related Measures. Hunan: Contemporary Education Forum.

Wu, F. (2003). American Society and Culture. Wuhan: Wuhan University Press.

Wang, J. J. (2014). Analysis of Sex Education in Children from Sexual Assault. Journal of Educational Institute of Jilin Province, 11, 14-15.

Wang, Q. D. (2008). Father Is Like Mountain, Mother Is Like Water. Beijing: World Knowledge Press. 
Submit or recommend next manuscript to SCIRP and we will provide best service for you:

Accepting pre-submission inquiries through Email, Facebook, LinkedIn, Twitter, etc. A wide selection of journals (inclusive of 9 subjects, more than 200 journals)

Providing 24-hour high-quality service

User-friendly online submission system

Fair and swift peer-review system

Efficient typesetting and proofreading procedure

Display of the result of downloads and visits, as well as the number of cited articles Maximum dissemination of your research work

Submit your manuscript at: http://papersubmission.scirp.org/

Or contact ce@scirp.org 